Federal Reserve Bank of Dallas

Globalization and Monetary Policy Institute

Working Paper No. 319

https://www.dallasfed.org/ /media/documents/institute/wpapers/2017/0319.pdf

\title{
The Second Era of Globalization is Not Yet Over: An Historical Perspective*
}

\author{
Michael D. Bordo \\ Rutgers University, NBER and the Hoover Institution, Stanford University
}

July 2017

\begin{abstract}
The recent rise of populist anti-globalization political movements has led to concerns that the current wave of globalization that goes back to the 1870 s may end in turmoil just like the first wave which ended after World War I. It is too soon to tell. The decline and then levelling off of trade and capital flows in recent years reflects the drastic decline in global real income during the Great Recession. Other factors at work include the slowdown in the growth rate of China and the reversal of the extended international supply chains developed in the 1990s, as well as increased financial regulation across the world after the crisis. This suggests either a pause in the pace of integration or more likely a slowing down, rather than a reversal.
\end{abstract}

JEL codes: N1, F6

* Michael D. Bordo, Department of Economics, Rutgers University, 75 Hamilton Street, New Brunswick, NJ 08901-1248. 732-932-7069. bordo@econ.rutgers.edu. Paper prepared for the Reinventing Bretton Woods Conference “Living Without Globalization”, Hamburg, Germany, July 3-4, 2017. The views in this paper are those of the authors and do not necessarily reflect the views of the Federal Reserve Bank of Dallas or the Federal Reserve System. 


\section{Introduction}

The recent rise of populist anti-globalization political movements has led to concerns that the current wave of globalization that goes back to the 1870s may end in turmoil just like the first wave which ended after World War I.

Globalization, defined as the integration of the markets for goods, labor and financial capital, displayed a U-shaped pattern from 1870 until just recently (Bordo, Taylor and Williamson (2004)). It was high in the late nineteenth century and early twentieth century and then dropped significantly between World War I and World War II. It recovered in the post-World War II period with the advent of GATT and later WTO and the end of Bretton Woods capital controls and has been growing at least until the Great Financial Crisis of 2007-2008. The first era of globalization ended because of a backlash by the losers of globalization in Europe, the U.S., and elsewhere leading to an increase in tariff barriers, capital controls and restrictions on immigration. It also ended because of the breakdown in the international political order leading to World War I and its subsequent upheavals in Europe and Asia. Many observers worry that a repeated backlash is in the works at present or in the near future. The data (see below) shows a decline and then flattening in world trade and capital flows since the GFC but not in migration. This is viewed by some as a portent of bad things to come.

I argue that it is too soon to tell. The decline and then levelling off of trade and capital flows reflects the drastic decline in global real income during the Great Recession. Other factors at work include the slowdown in the growth rate of China and the reversal of the extended international supply chains developed in the 1990s, as well as increased financial regulation 
across the world after the crisis. This suggests either a pause in the pace of integration or more likely a slowing down.

\section{U shaped Pattern of Globalization}

\subsection{International Trade.}

The growth of trade relative to population and income began in earnest in the early nineteenth century. It was driven by technological change which vastly reduced the costs of shipping goods, a reduction in tariffs and political stability (see Figure 1 Panel A). Empirical evidence for globalization is based on two dimensions: a) the growth of international trade relative to income; b) convergence in the price of traded commodities (Findlay and O'Rourke (2004)). On both dimensions, although the process of informational integration began with the opening up of the world with the Age of Discovery in the sixteenth century, the major spurt in globalization did not really occur until after the Napoleonic wars. The growth of trade from 1500 to 1800 averaged a little over one per cent per year, while population grew by 0.25 per cent. Between 1815 and 1914 trade measured by exports grew by 3.5 per cent per year versus income growth of 2.7 per cent. In the twentieth century, as a whole, trade growth was similar but did not outpace the growth of output to the same extent as in the previous century.

Commodity price convergence was also dramatic in the nineteenth century. For example, because of a massive decline in transportation costs (steamships and railroads) the price of wheat in Liverpool relative to Chicago fell from $58 \%$ in 1870 to $16 \%$ in 1913.

In addition to falling transport costs, globalization was spread by big reductions in tariff protection, beginning with Britain's reduction of the Corn Laws (tariffs on grain) after the 
Napoleonic Wars and culminating in their abolition in 1846. The movement towards free trade spread across Europe in a series of reciprocal agreements beginning with the Cobden Chevalier Treaty in 1860 between Great Britain and France. Within the next two decades virtually all of Europe reduced tariffs (to the $10-15 \%$ range from $35 \%$ ) in a series of bilateral agreements incorporating Most Favored Nation clauses.

The liberalization process was temporarily reversed after 1879 with the introduction of tariffs by Germany and France and then other countries. A decline in land rents consequent upon declining world agricultural prices led to a backlash and a renewal of protection ( $O^{\prime}$ Rourke, Taylor and Williamson (1996)), although the level of effective protection (with the principal exception of the U.S.) still remained low until 1914.

World War I disrupted trade with tariffs and quotas and then after the war the movement toward protection increased. The U.S. with the Fordney McCumber tariff of 1922 and then the Smoot Hawley tariff of 1930 was the worst offender. Other countries retaliated, e.g. Great Britain with the Ottawa Agreement of 1932. The Great Depression led to increasing tariffs to stimulate recovery. By the eve of World War II multilateral trade collapsed into a system of bilateral trade and quotas (see Figure 1 Panel B).

Trade and globalization revived after World War II with the GATT (General Agreement on Tariffs and Trade) which was created by the international community - along with the IMF, World Bank and other international organizations. Successive rounds of tariff negotiation from 1947 to the 1990s virtually eliminated tariffs on manufactured goods in advanced countries. The WTO (World Trade Organization), which succeeded GATT in 1994, has been engaged in reducing tariff barriers and protection in services and agriculture in areas not covered by GATT. It also includes emerging 
market countries in its mandate. As can be as seen by Figure 1 Panel C, by the 1970s the ratio of trade to GDP reached the level of the earlier era of globalization.

\subsection{Capital Flows}

Like the market for goods, international financial markets enjoyed two eras of globalization, from 1870 to 1914 and since 1973 . The pace of international integration of finance (capital), followed a U-shaped pattern (Obstfeld and Taylor (2004)) with integration interrupted by the imposition of capital controls in the era of the World Wars, the Great Depression and the Bretton Woods System.

The U-shaped pattern of financial globalization can be seen in Figure 2, which shows net capital flows from 1870 to the present for 12 advanced countries, and Figure 3, which adds in a number of emerging countries since 1973 . Within this long sweep of data, we can see four episodes: 1) 1870 to 1914 the era of the classical gold standard with London at the center. Adherence to the gold standard ensured stable exchange rates and acted as a commitment mechanism or "Good Housekeeping Seal of Approval" (Bordo and Rockoff (1996)). During this period, massive capital flows led to the convergence of interest rates across countries; 2) 1914 to 1945, World War I, the Great Depression and World War II disrupted the pattern of financial globalization as capital and exchange controls were instituted; 3)1945 to 1973, the Bretton Woods era. Trade resumed under Bretton Woods but member countries had to impose capital controls; 4)1973 to the Great Financial Crisis. This is an era of floating exchange rates and the removal of capital controls. 
Obstfeld and Taylor (2004) explain this U-shaped pattern in financial market integration in terms of Mundell's policy trilemma between open capital markets, pegged exchange rates and independent monetary policy. Only two of the three can hold at the same time.

\subsection{Migration}

Like the commodity markets and capital flows, international migration surged in the nineteenth century, declined after World War I. Before the nineteenth century, migration from the Old to the New World went through three stages: 1600 to 1790 , slaves and contract labor; 1790 to 1850 free settlers; 1850 to 1920, mass migration (Chiswick and Hatton (2004)). In the case of mass migration from Europe to primarily the U.S, Canada, Australia and Argentina, 300,000 per year moved between 1850 and 1880, 600,000 between 1880 and 1900, and over a million per year between 1900 and 1910 (see Figure 4). The wave of migration largely reflected economic factors (higher wages in the New World and reduced transportation costs).

As in the case of the commodity markets and financial flows, a backlash ensued in the face of declining real wages in the New World. Restrictions on immigration began in the 1890s, culminating in a virtual shutdown by the 1920s. Many of the restrictions were not removed until after World War II. In the decades before the Great Financial Crisis, although the absolute number of people moving to the U.S., Canada and Australia were similar to the pre-1910 period, the immigration rate for the U.S. was considerably lower than earlier, at 0.4 people per 1000 versus

\section{6 then.}

In the second era of Globalization the source of migration to the New World changed from Europe to Asia and Latin America recently. Also, in the recent era, legal migrants are much more 
highly skilled than pre-World War I, while there has been a surge in illegal (largely) unskilled migration from the poor countries of the world to the advanced countries. Frequent attempts in the advanced countries to stem this flow have been largely unsuccessful.

\subsection{The Backlash}

The first era of globalization ended badly with World War I, the Great Depression, and World War II. But even before the demise there was a considerable backlash against it. James (2001) and O'Rourke and Williamson (1999) argued that the process of globalization embodied the seeds of its own destruction. The consequences of trade and factor mobility in the Golden Age was the convergence of real wages and per capita real income between the Core countries of Western Europe and much of the periphery. According to Williamson (1996), this reflected the operation of classical trade theory. Both factor flows and goods flows fostered factor price equalization. Most of the convergence in real wages (70\%) is explained by factor movements, especially by labor mobility, (with mobile capital a minor player); the rest $(30 \%)$ by international trade, according to the Hecksher-Ohlin theorem.

These forces had important effects on the distribution of income. The massive migrations in the 1870 to 1914 period reduced the returns to land owners in the land-scarce, labor-abundant countries of Europe and at the same time worsened the income distribution in the countries of recent settlement, as unskilled immigrants competed with more established workers for jobs. A political backlash ensued in each region. In the Old World, landowners successfully lobbied for increased tariff protection of agriculture in the last two decades of the nineteenth century. In the U.S., Canada, Australia and Argentina, labor was ultimately successful in closing the doors to 
migrants by the second decade of the twentieth century. The backlash to globalization in turn may have fanned the flames of nationalism and been a key cause of World War I. The Great Depression made things worse as nations-in an attempt to protect their real incomes---raised tariff barriers and quotas, restricted immigration and terminated capital movements. We have now been for close to fifty years in the second era of globalization. Are similar forces at work? Are we on the brink of a massive deglobalization as occurred in the interwar period?

\section{Since the Great Financial Crisis: Is the Second Era of Globalization over?}

\subsection{Trade}

The global financial crisis of 2007-2008 led to a decline in world income not seen since the 1930s (Eichengreen and O'Rourke (2009)). World trade declined (by 10\%) much more than world output and then snapped back to positive territory by 2011 (see Figure 5). But the growth of the ratio of trade to output from 2011-2015 declined dramatically compared to before the GFC, from $6.35 \%$ per year to 3.3\% (OECD (2015), IMF (2015)). Much of the decline in trade reflected cyclical forces - the collapse in aggregate demand after the GFC, especially the collapse in investment which depended on inputs from abroad (OECD (2015)). But secular forces were also important. These included the collapse of the global supply chain, which had developed slowly in the 1980s between the advanced countries of North America, Europe and Japan on the one hand and China and other emerging Asian economies on the other hand (Baldwin (2016)). The development of just in time production techniques led to the formation of completely integrated global enterprises, operating world-wide and combining advanced countries technical knowhow with emerging market lower cost labor (e.g. Walmart). These supply chains collapsed in the GFC and 
have not been fully restored yet. Moreover, the global supply chains in the GFC model has run into diseconomies of scale. This has led many global firms to localize their production (WSJ (2016)). Another structural factor that can explain the significant drop in the growth of trade relative to output is the slowing down in China (the key player after the U.S. with $15 \%$ of world GDP) from above $9 \%$ per year before the crisis to $6.5 \%$ today. This reflects very deep structural forces including slow population growth as a consequence of the one child policy and the absorption of labor from the agricultural sector (Eichengreen (2016)). A less important structural factor for the decline in trade to GDP is increasing protection since the crisis (Hufbauer (2010)). This is very different from what happened in the 1930s, when the rise of tariff protection was the key determinant of the collapse of global trade (Irwin (2010)). Thus, globalization in trade has downshifted. The interesting questions is whether this is temporary or permanent.

\subsection{Capital Flows}

Capital flows also collapsed in the GFC and have not returned to their previous trend (see Figure 6). This reflects a number of forces: the slowdown in the real economy, risk aversion after the crisis, and increased regulation of banks and the financial sector in every country as well as at the international level (Basel III). As in the 1930s, banks were blamed for the crisis and regulation of them increased considerably.

As dramatic as the collapse in international capital flows is the collapse of cross border bank lending (see Figure 7). According to Forbes et al. (2016), it reflected the effects of increased regulation, especially the use of micro prudential policy (an increase in the capital requirements on cross border loans relative to domestic loans in BASEL III) which interacted with 
unconventional monetary policy. Capital flows have recovered since the crisis but are at a much lower level.

\subsection{Migration}

The growth of immigration to the New World has slowed since the GFC but did not collapse (see Figure 8). The problem of refugees and illegal immigration has increased drastically in Europe reflecting political instability in the Middle East and Africa.

\section{Summary}

The recent empirical evidence suggests that the Global Financial Crisis was a huge shock which has stalled the pace of globalization and may be the beginning of a reset. As well, like in the first era of globalization, there has been a populist political backlash against globalization. Just as in the first era of globalization the losers have turned to political action (largely triggered by the income shock of the GFC but also deep seated dislocation from import competition). Autor et al. (2016) and others have provided evidence that, since China joined the WTO in 2000, imports of manufactured goods have displaced large numbers of workers in the U.S. (on top of lesser dislocation from NAFTA earlier) and Western Europe. These losers from both globalization and technological change have been opponents of globalization providing support to populist candidates (Dippel et al. (2015)).

Will the current slowing down and possible resetting of globalization mark the beginning of the end of the second era of globalization? That outcome seems unlikely for a number of reasons: 1) the growth of international trade is more widespread than pre-1914 and, hence, the groups that 
may be harmed are outweighed by those that would benefit (e.g. shoppers at Walmart). 2) Today there are more escape valves in trade legislation to reduce trade pressure than in the first era of globalization. 3) Unlike in the pre-1914 era, trade disputes can be resolved by multinational agencies such as the WTO, which were not present then. 4) Many countries made progress in adopting policies to help the losers in the globalization game in the form of compensation packages and retraining schemes. Although they obviously have not been enough to prevent a backlash. 5) Most countries in recent years have learned to pursue stable macroeconomic policies. This is in sharp contrast to the unstable macroeconomic environment that led to the shutting down of the capital markets in the 1930s. Indeed, the lessons of the Great Depression have been well learned by the Federal Reserve and other central banks in 2007-2008 to prevent a repeat of the global financial meltdown that had occurred in 1931. 6) The global proliferation of large multinational enterprises and financial entities is very different from pre-1914. The cost of unraveling this seamless web of interconnections with tariffs and other trade impediments would be disastrous.

On the other hand, Rodrik (2013) has posited that there is a conflict between globalization and sovereignty. His political economy trilemma between hyper globalization (the Washington Consensus), democracy and the nation state points out the tradeoffs that define the globalization debate. The form of globalization we end up with may very well reflect these forces.

\section{Conclusion}

The prediction for the future of globalization depends heavily on the direction of the political forces at play in the world today. Negative political shocks may reduce the growth of trade. But 
positive shocks like the recent French elections may reverse these forces. The increased regulation of the financial system may throw sand in the wheels of financial globalization and the anti-immigrant sentiment in many countries may slow the growth of migration.

But the real question is whether these short-run forces will change the long-run dynamics of international capitalism. Millions of people have been lifted from poverty in the second era of globalization and millions of others have had significant increases in their living standards. The losers from globalization are a vocal minority, but still a minority.

The bottom line is that the second era of globalization is not ending. It is going through a rest following the Global Financial Crises and the Great Recession and the inevitable political reaction to these events. 


\section{Appendix A. Figures}

Figure 1. World Trade and Output
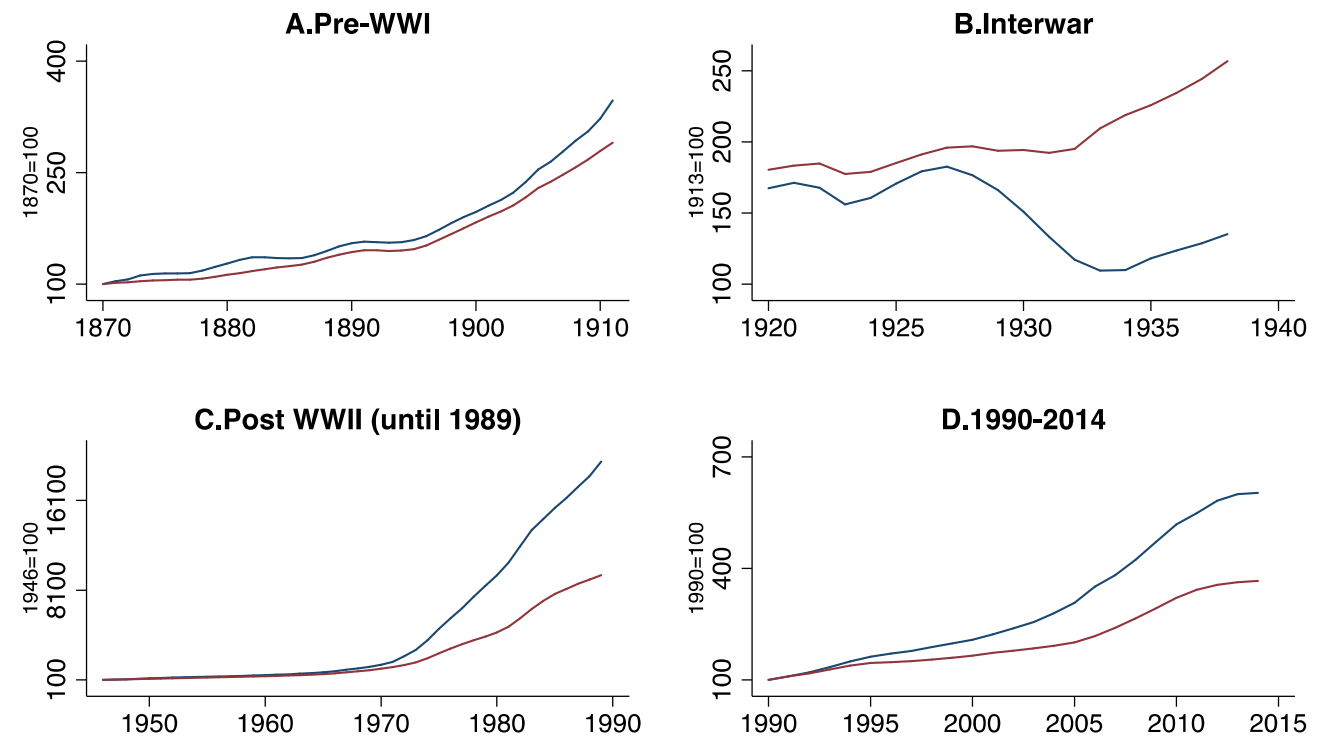

Export volume

Output

Source: Fouquin \& Hugot (2016)

Figure 2. Net Capital Inflows for Selected Countries*

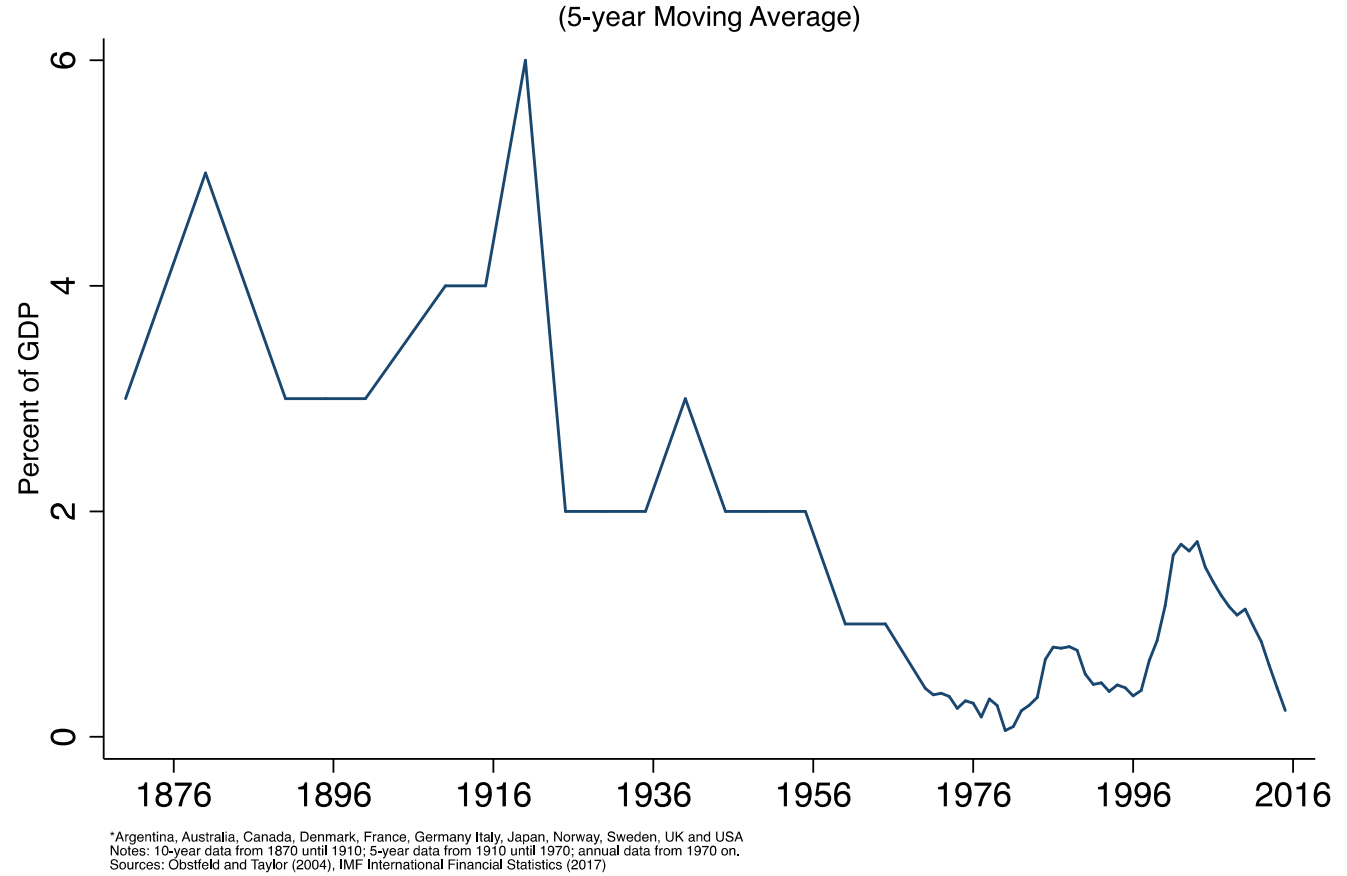


Figure 3. Current Account Balance to GDP
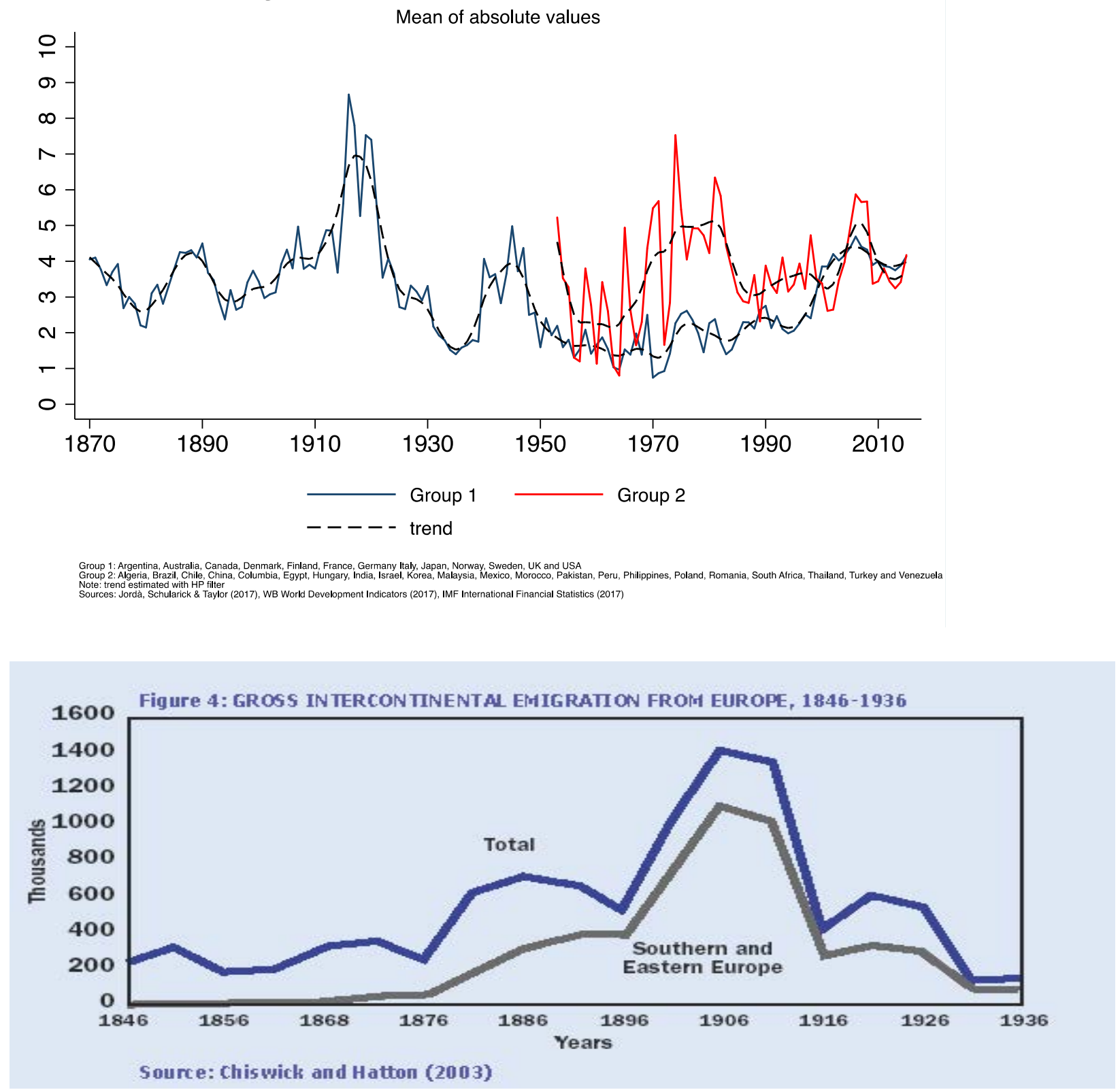
Figure 5. World Trade and Output

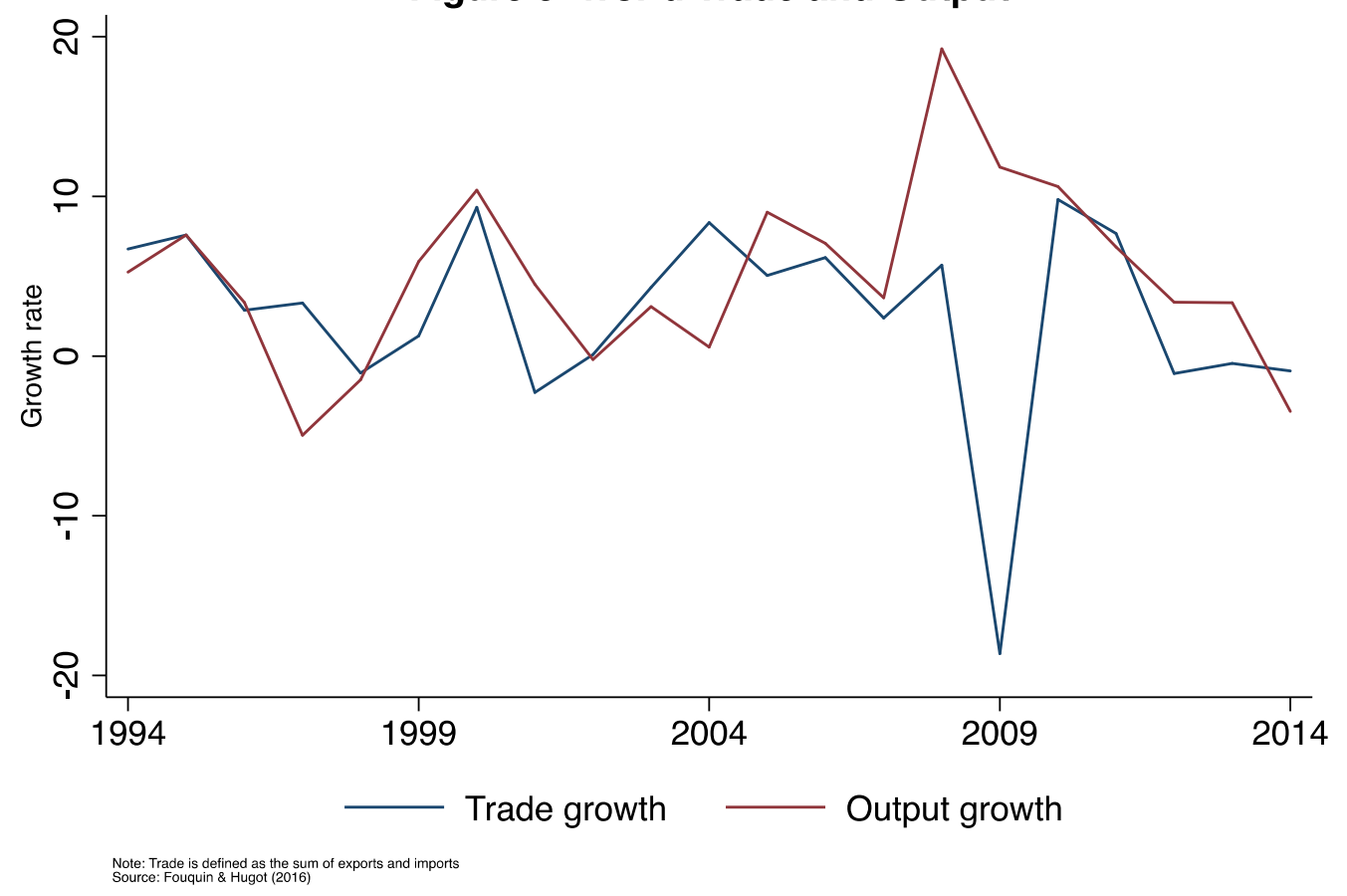

Figure 6. Net Capital Inflows for Selected Countries*

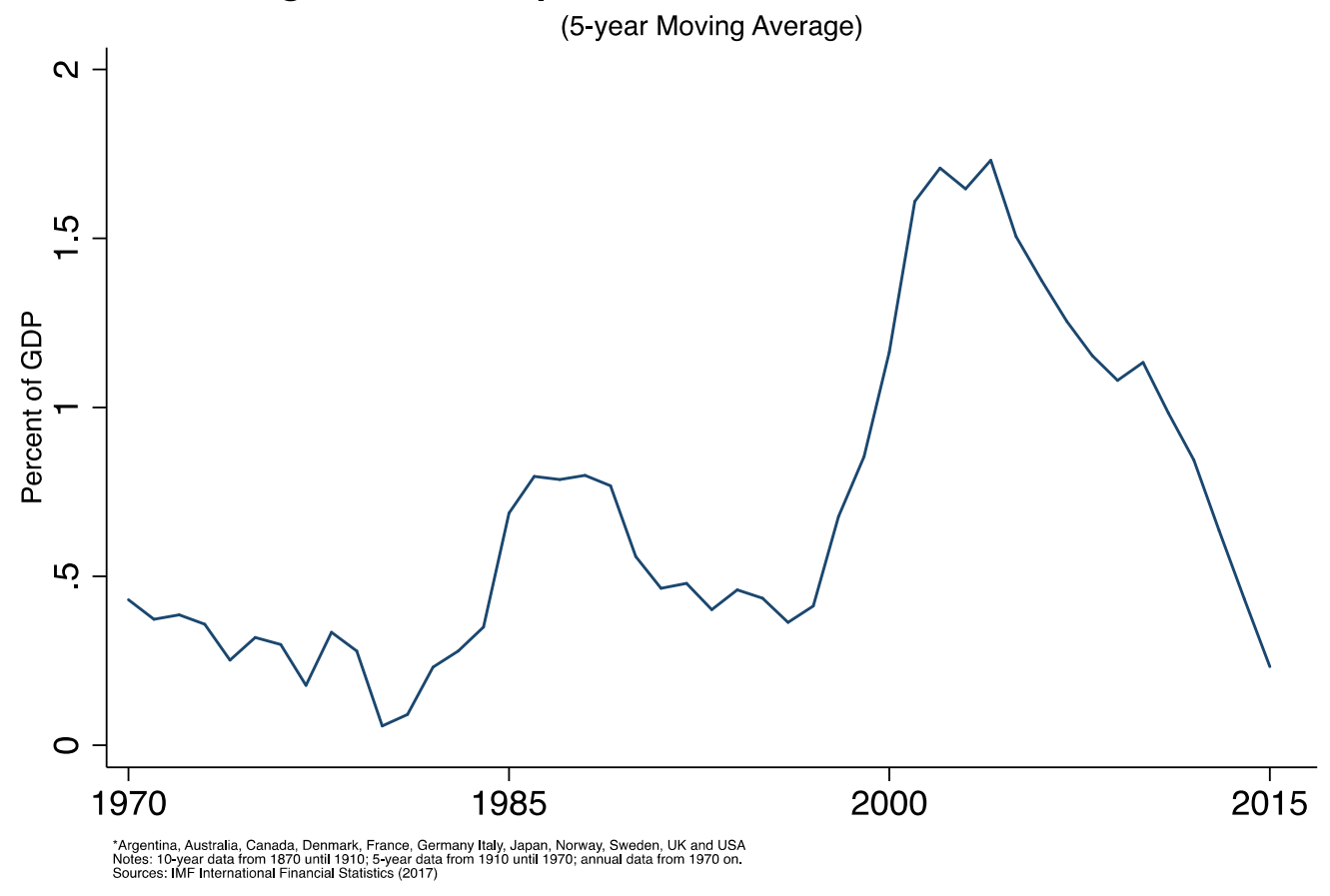


Figure 7. Cross-border financial flows took a dive in the crisis of 2008*

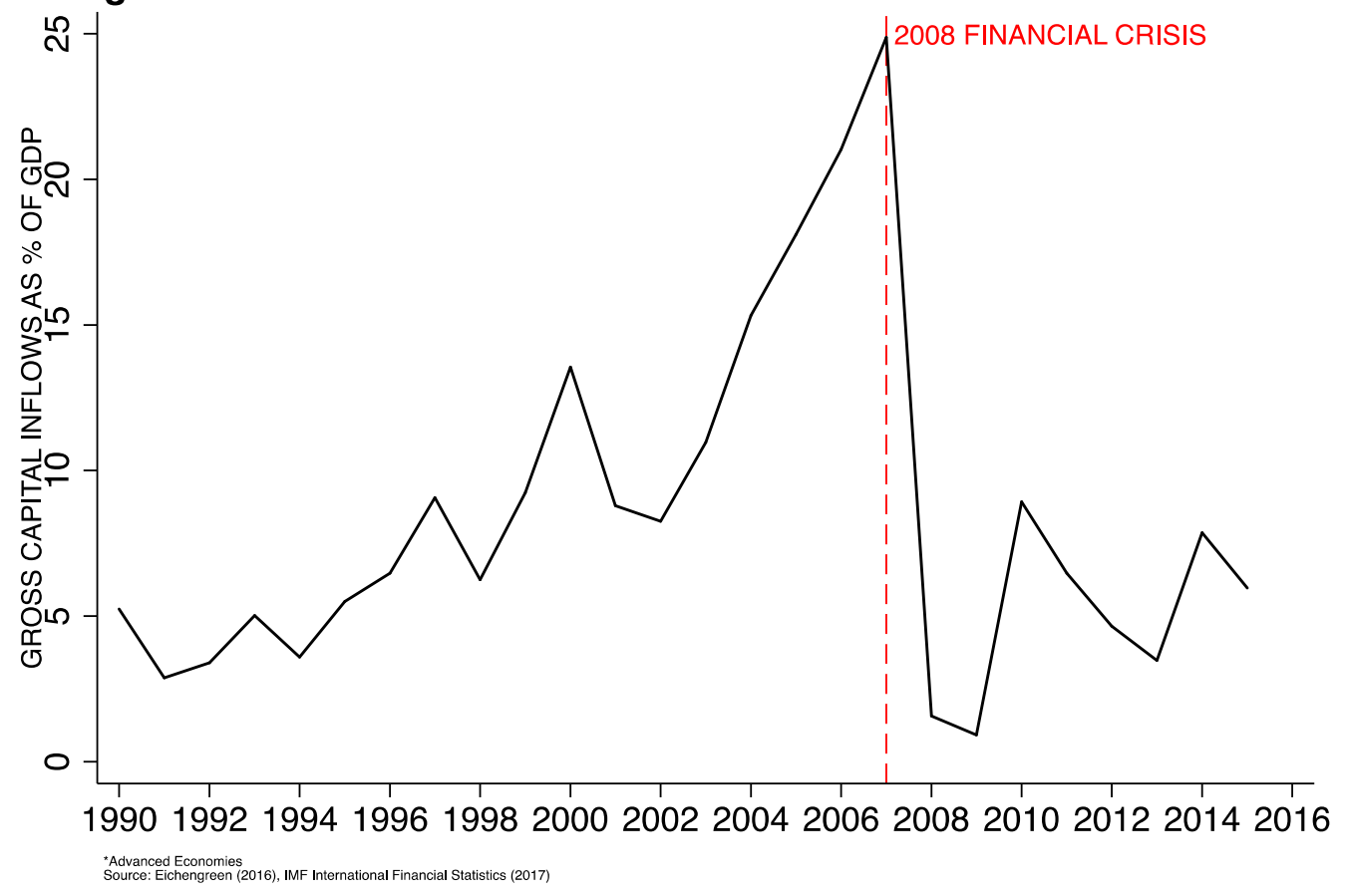

Figure 8. Immigration flows by Region

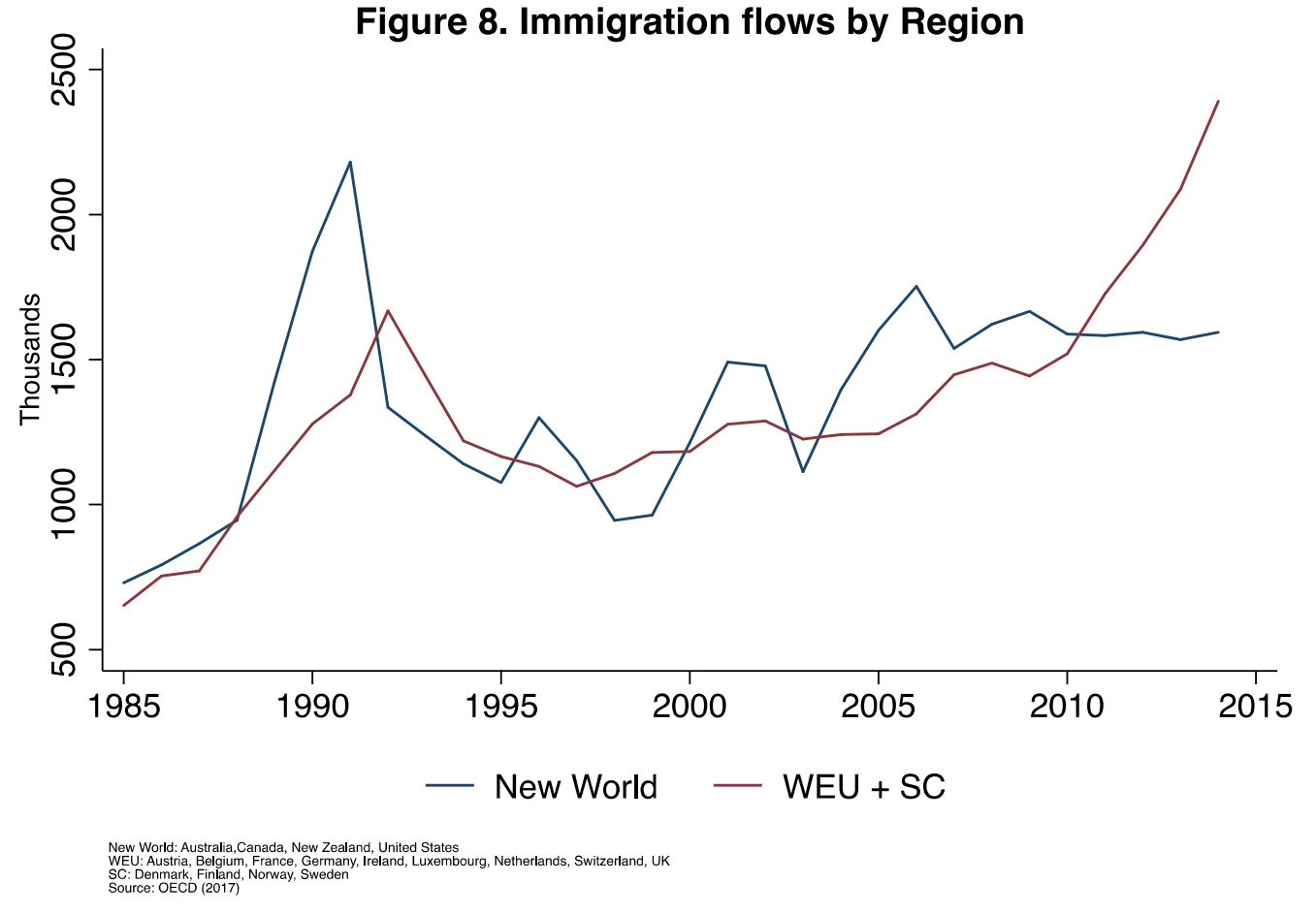




\section{References}

Autor, David, David Dorn, Gordon Hanson, and Kaveh Majlesi. 2016. "Importing political polarization? the electoral consequences of rising trade exposure." NBER Working Paper 22637 (2016).

Baldwin, Richard. 2016. The Great Convergence. Harvard University Press, 2016.

Bordo, Michael D., and Hugh Rockoff. 1996. "The gold standard as a "good housekeeping seal of approval"." The Journal of Economic History 56.02 (1996): 389-428.

Bordo, Michael D., Alan M. Taylor and Jeffrey G. Williamson, eds. 2004. Globalization in historical perspective. University of Chicago Press.

Chiswick, Barry, and Timothy J. Hatton. 2004. "International migration and the integration of labor markets." in Globalization in historical perspective, edited by Michel D. Bordo, Alan M. Taylor and Jeffrey G. Williamson. University of Chicago Press, 65-120.

Dippel, Christian, Robert Gold, and Stephan Heblich. 2015. “Globalization and its (dis-) content: Trade shocks and voting behavior". No. w21812. National Bureau of Economic Research, 2015.

Eichengreen, Barry. 2016. “Will Globalization go into reverse?” Prospect Magazine, November 2016 (248) 
Eichengreen, Barry, and Kevin H. O' Rourke. 2009. "A tale of two depressions." VoxEU. org 1 (2009).

Fouquin, Michel and Jules Hugot. 2016. "Two Centuries of Bilateral Trade and Gravity Data: 18272014," CEPII Working Paper 2016-14, May 2016 ,CEPII.

Irwin, Douglas ( 2009) “World Trade and Production" VoxEU

James, Harold. 2001. The end of globalization: lessons from the Great Depression. Harvard University Press, 2001.

Jordà , Òscar, Moritz Schularick, and Alan M. Taylor. 2017. “Macrofinancial History and the New Business Cycle Facts." in NBER Macroeconomics Annual 2016, volume 31, edited by Martin Eichenbaum and Jonathan A. Parker. Chicago: University of Chicago Press.

Findlay, Ronald, and Kevin H. O'Rourke. 2004. "Commodity market integration, 1500-2000." Globalization in historical perspective. University of Chicago Press, 13-64.

Forbes, Kristin J., Dennis Reinhardt and Tomasz Wieladek. 2016. "Banking De-Globalisation: A Consequence of Monetary and Regulatory Policies?" (September 2016). BIS Paper No. 86h. 
Hufbauer, Gary C. 2010. Globalization at Risk. Yale University Press, 2010.

IMF. 2015. The Global Trade Slowdown: Cyclical or Structural?

Obstfeld, Maurice, and Alan M. Taylor. 2004. Global Capital Markets: Integration, Crisis, and Growth. Cambridge: Cambridge University Press

OECD. 2015. “Explaining the Global Trade Slowdown and Re-Invigorating Trade's Contribution to Growth"

O'Rourke, Kevin H., Alan M. Taylor, and Jeffrey G. Williamson. 1996. "Factor Price Convergence in the Late Nineteenth Century." International Economic Review (1996): 499-530.

O'Rourke, Kevin H., and Jeffrey G. Williamson. 1999. Globalization and history: The evolution of a 19th century Atlantic economy. MIT Press 6 (1999): 100-105.

Rodrik, Dani. 2013 The Globalization Paradox: Democracy and the Future of the World Economy WW Norton New York

Williamson, Jeffrey G. 1996. "Globalization, convergence, and history." The Journal of Economic History 56.02 (1996): 277-306. 
Wall Street Journal. 2016. "Risk of Deglobalization Hangs Over World Economy" by Simon Nixon, Oct. 52016. 